Article

\title{
Assessment of Durum Wheat (Triticum durum Desf.) Genotypes Diversity for the Integrated Production of Bioethanol and Grains
}

\author{
Donatella Danzi $^{1, *(\mathbb{D})}$, Ivana Marino ${ }^{2}$, Isabella De Bari ${ }^{3}$, Silvio Mastrolitti ${ }^{3}$, Giacomo L. Petretto ${ }^{4} \mathbb{D}$, \\ Domenico Pignone ${ }^{1,5}$ (D), Michela Janni ${ }^{1}$, Francesco Cellini ${ }^{2}$ and Tullio Venditti ${ }^{6, *(D)}$
}

1 Institute of Biosciences and Bioresources, National Research Council, 70126 Bari, Italy; domenico.pignone@cnr.it (D.P.); michela.janni@ibbr.cnr.it (M.J.)

2 Agenzia Lucana di Sviluppo e Innovazione in Agricoltura, Centro Ricerche Metapontum Agrobios, 75012 Bernalda, Italy; ivana.marino@alsia.it (I.M.); francesco.cellini@alsia.it (F.C.)

3 ENEA C.R. Trisaia, 75026 Rotondella, Italy; isabella.debari@enea.it (I.D.B.); silvio.mastrolitti@enea.it (S.M.)

4 Department of Chemistry and Pharmacy, University of Sassari, 07100 Sassari, Italy; gpetretto@uniss.it

5 Institute of Veterinary and Agrifood Bioethics, 00054 Fiumicino, Italy

6 Institute of Sciences of Food Production, National Research Council, 07100 Sassari, Italy

* Correspondence: donatella.danzi@ibbr.cnr.it (D.D.); tullio.venditti@cnr.it (T.V.)

check for

updates

Citation: Danzi, D.; Marino, I.; De Bari, I.; Mastrolitti, S.; Petretto, G.L.; Pignone, D.; Janni, M.; Cellini, F.; Venditti, T. Assessment of Durum Wheat (Triticum durum Desf.) Genotypes Diversity for the Integrated Production of Bioethanol and Grains. Energies 2021, 14, 7735. https://doi.org/10.3390/en14227735

Academic Editor: Mariusz J. Stolarski

Received: 5 October 2021

Accepted: 8 November 2021

Published: 18 November 2021

Publisher's Note: MDPI stays neutral with regard to jurisdictional claims in published maps and institutional affiliations.

Copyright: (c) 2021 by the authors. Licensee MDPI, Basel, Switzerland. This article is an open access article distributed under the terms and conditions of the Creative Commons Attribution (CC BY) license (https:// creativecommons.org/licenses/by/ $4.0 /)$.

\begin{abstract}
Wheat straw is an abundant source of lignocellulosic biomass that is generally not utilized for biofuel production, nor for other uses. Recent EU renewable energy directive fosters bioethanol production through lignocellulosic sugars fermentation, but the cost of this process is an issue that often depends on biomass characteristics. Lignin is a class of three-dimensional polymers providing structural integrity of plant tissues. Its complex structure, together with hemicelluloses and uronic acids content, could affect the ability of hydrolyzing biomass to fermentable sugars. To get insights into this variation, a set of 10 durum wheat genotypes was analyzed to determine variation of straw digestibility to fermentable sugars. The results showed that the lignin content was the major factor determining the recalcitrance to enzymatic process. The analysis of Spearman's correlation indicated that the sugar released after enzymatic hydrolysis had a negative connection with the lignin content, while it was positively correlated with the culm length. The possible role of other cell wall components, such as arabinose and uronic acids, was also discussed. This work aimed at analyzing the diversity of lignocellulosic digestibility to fermentable sugars of wheat straw in a small germplasm collection. Some of the selected genotypes were characterized by high sugars digestibility and high grain yield, characteristics that could make biorefining of wheat straw profitable.
\end{abstract}

Keywords: lignocellulosic biomass; biofuel; genotype; lignin content; recalcitrance; saccharification

\section{Introduction}

The depletion of fossil sources, combined with the growing energy demand, has increased the interest in the use of alternative energy sources meeting renewability, costefficiency, and sustainability. Biofuels, namely bioethanol, biodiesel, green diesels, etc., offer several advantages over fossil fuels in terms of production and use. They have high oxygen contents (10-45\% higher than petroleum feedstock), which implies lesser $\mathrm{CO}_{2}$ emission [1], even if some of these fuels have also a lower heating value, because of the oxygen content. Moreover, the use of liquid biofuels would require fewer adaptations of the existing fueling systems, since they could be used alone or blended with traditional fuels [2].

Bioethanol can replace an important part of the fossil fuels used in the transport sector. First-generation biofuels are produced from types of biomass that are often used for food, such as corn, soy, sugarcane, and sugar beet [3]. These biofuels are made through fermentation or chemical processes that convert the oils, sugars, and starches present in the 
biomass into liquid fuels. First-generation biofuel crops are seen as competing directly with food, and any displacement of food crops due to biofuel crop production could decrease food supply and increase food prices [4]. These concerns have given rise to an interest in a second generation of biofuel crops that represent a possible way to avoid direct competition with food production, since the feedstock for bioethanol could be derived from edible parts of food crops [5].

Second-generation bioethanol meets these requirements since it can be produced from the residual non-food parts of lignocellulosic biomass (LB) [6], such as sugarcane bagasse, corn cobs, coconut husks, cereal straw, corn stover, rice straw, or agricultural wastes [7].

The main source of LB is plant secondary cell wall (CW), whose chemical composition varies among species, with developmental stage and as a consequence of environmental conditions. The main structural molecules of CW are cellulose, hemicelluloses, lignin and pectins $[8,9]$.

The cellulose is the major structural component within the plant $\mathrm{CW}$, responsible for mechanical strength. Cellulose is a very simple polysaccharide that exists in the form of microfibrils formed by unbranched chains of continuous $\beta$-1,4-glucopyranosyl residues, hydrogen-bonded to one another. They are attached via hydrogen bonds to the hemicelluloses, the second most abundant polymer that mainly consist of xyloglucans, arabinoxylans, and other polysaccharides.

Xyloglucans is the predominant hemicellulose in dicotyledons and non-graminaceous monocotyledons, but in the graminaceous monocots, the predominant hemicellulose is arabinoxylan. Hemicelluloses are polysaccharides usually branched that are structurally homologous to cellulose: xyloglucans have a backbone composed of $\beta$-1,4-glucosyl residues, with short side chains, arabinoxylan also has a cellulose-like backbone that consist of $\beta-1,4$-xylosyl residues.

The CW contains large amounts of lignin, responsible for hydrophobicity and structural rigidity. Lignin is a complex heteropolymer that primarily consists of p-hydroxyphenyl, guaiacyl, and syringyl units formed by the oxidative coupling of p-coumaryl, coniferyl, and sinapyl alcohols, respectively, which are products of the phenolpropanoid pathway $[10,11]$. The lignin content shows a large variability among species-in general, in monocotyledons, it ranges between 5\% and 35\% and in hardwoods between 15 and 30\% [12].

Wheat straw is an abundant biomass residue of wheat cultivation and potential source of feedstock for bioethanol $[13,14]$. An estimate of annual global wheat straw residues can reach 887 million tons, a feedstock source of great potential economic and ecological value [14], however, in many developing countries, crop residues are burnt on farms after harvest seasons, generating large amounts of greenhouse gases [15]. Li and Chen [16] estimated in 354 million tons, the annual global quantity of agro-losses for wheat straw.

The conversion of biomass into bioethanol requires three main steps: (I) pretreatment necessary to remove the structural layers of lignin that package cellulose and hemicellulose, allowing the action of the cell-wall degrading enzymes (CWDEs); (II) saccharification, consisting in the degradation of the CW polysaccharides to sugar monomers; (III) microbial fermentation of sugar monomers into ethanol $[17,18]$.

Different pretreatments_-thermal, physico-chemical and biological-have been reported, often implying high costs of the process and contributing to environmental issues. Recalcitration of CW to enzymatic hydrolysis is considered the main bottleneck in the exploitation of wheat biomass [19-21].

The sugar yield of wheat straw depends on several genotypic and phenotypic characteristics [22,23]. Secondary CW chemical composition, morphology, and distribution of plant parts, such as leaf, nodes, internodes, and spike are reported to affect the enzymatic digestibility. In fact, Lindedam et al. [24] demonstrated that both sugar conversion rates and sugar release are positively correlated with plant height.

Genetic engineering, especially for crops directly consumed by humans, is problematic because regulations for genetically modified crops are very strict. Among durum wheat 
genotypes, there is a large biodiversity that could be exploited without regulatory hurdles, to identify those varieties characterized by a low recalcitrance to enzymatic hydrolysis of the lignocellulosic fraction and high grains yield.

This paper focused on the analysis of eight durum wheat genotypes selected from a germplasm collection and two reference varieties, Cappelli and Saragolla. The present work represents a preliminary study, performed without biomass pretreatment, to identify those varieties naturally characterized by a low recalcitrance to enzymatic hydrolysis of the lignocellulosic fraction. Plants were characterized for the biochemical aspects of their CW, as well as for their morphological traits. The correlations among the above characteristics were analyzed to identify the genotypes with a potential of feedstock for biorefining while maintaining an acceptable grain yield.

\section{Materials and Methods}

\subsection{Plant Material, Growth Conditions, and Phenotypic Traits}

Ten durum wheat samples (Triticum durum Desf.) were grown at the ALSIAMetapontum Agrobios Research Center (40.392235 N, 16.786908 E). Two Italian varieties, Cappelli and Saragolla, and eight genotypes belonging to a core durum wheat germplasm collection, selected through the Single Seed Descendent method and hereafter referred as SSD collection $[25,26]$, were used. The complete list of the genotypes utilized for the experiment and their origin area was detailed in Table 1. Seeds were germinated at room temperature for $3 \mathrm{~d}$ in Petri dishes, on wet filter paper, to ensure relative humidity close to saturation and then transplanted into polystyrene trays. The trays were stored at $4{ }^{\circ} \mathrm{C}$ for 2 weeks to synchronize plants development. Plants were then transferred into twoliter pots filled with a 1:1 $(v / v)$ mixture of river sand and peat moss and grown under natural light conditions until complete plant ripeness (Z94) [27]. After harvesting, three quantitative phenotypic traits such as kernel yield (K), biomass dry weight (B), and main culm length $(\mathrm{H})$ were evaluated. Kernel yield was expressed as $\mathrm{g}$ of kernel per plant and the biomass was expressed as $g$ of dry biomass per plant. The main culm length was measured from the surface of the soil to the collar of the flag leaf and expressed in $\mathrm{cm}$ [28]. According to the three categories indicated by Pignone et al. [25], wheat plant size was classified as large $(L=H>150)$, medium $(M=110<H \leq 150)$, and small $(S=H \leq 110)$. All measurements were reported as the mean of 10 plants used as replicates. The wheat straw of three biological replicates was ground using a laboratory mill (Pulvisette, Fritsch Gmbh, Idar-Oberstein, Germany) equipped with a $0.2 \mathrm{~mm}$ grid. The samples were used for enzymatic hydrolysis, lignin Klason and CW analyses.

Table 1. SSD entry names and origins of the durum wheat genotypes.

\begin{tabular}{cc}
\hline SSD Entry & Origin \\
\hline 7 & Portugal \\
69 & Morocco \\
96 & Azerbaijan \\
180 & India \\
240 & Ethiopia \\
283 & France \\
411 & Greece \\
467 & Greece \\
CAPPELLI & Italy \\
SARAGOLLA & Italy \\
\hline
\end{tabular}

\subsection{Lignin Klason Analysis}

To quantify the acid insoluble lignin (Klason lignin), biomass was first treated to remove the extractives [29], and then analyzed according to the NREL standard methods [30]. Briefly, the extractives removal was performed on $1.5 \mathrm{~g}$ of oven dried biomass. The samples were threefold sequentially extracted with a total volume of $37 \mathrm{~mL}$ ethyl 
alcohol (MERCK-ACS spectrophotometric grade 95\%) using a Dionex Automated Solvent Extractor (ASE-200) system. The extracted samples were then air dried for $24 \mathrm{~h}$. The lignin analysis was performed on $300 \mathrm{mg}$ extractives-free samples, which were digested into a pressure tube with $3 \mathrm{~mL}$ of $72 \%$ sulfuric acid for $60 \mathrm{~min}$ in a water bath at $30{ }^{\circ} \mathrm{C}$. Additionally, $84 \mathrm{~mL}$ of deionized water were added to complete the hydrolysis in autoclave at $121^{\circ} \mathrm{C}$ for $1 \mathrm{~h}$. The obtained solution was vacuum filtered through glass fiber filter (porosity $0.45 \mu \mathrm{m}$ ) previously weighed. The acid insoluble lignin was quantified by weighing the filtered residue, after overnight drying at $105^{\circ} \mathrm{C}$ and expressed as $\mathrm{mg}$ of lignin $\mathrm{g}^{-1}$ of biomass. The lignin data were not corrected by subtracting their ash content, the resulting weight is the sum of lignin and ash. The experiment was repeated twice.

\subsection{Secondary Cell Wall Yield and Isolation}

Approximately two grams of straw from each durum wheat genotype, grinded as described above, were boiled in $40 \mathrm{~mL}$ of 95\% ethanol (Sigma-Aldrich, Darmstadt, Germany) with continuous stirring for $45 \mathrm{~min}$, to ensure enzyme inactivation, prevent autolytic breakdown of wall polymers and to extract low molecular weight solutes. The insoluble material was filtered through glass fiber filters (Whatman, Dassel, Germany) and sequentially washed with $25 \mathrm{~mL}$ of ethanol, $25 \mathrm{~mL}$ of a mixture of methanol/chloroform (ratio $1: 1, v / v)$ (Sigma-Aldrich) and $25 \mathrm{~mL}$ of acetone (Sigma-Aldrich), yielding the crude CW extract (alcohol insoluble residue, AIR). The AIR was dried overnight at $37^{\circ} \mathrm{C}$ and weighed; results were expressed as percentage of AIR respect to the biomass.

\subsection{Uronic Acids and Total Sugars Measurements}

About $3 \mathrm{mg}$ of AIR were solubilized in concentrated $\mathrm{H}_{2} \mathrm{SO}_{4}$ (Carlo Erba, Cornaredo, Italy) [31] and aliquots of the AIR solution were evaluated for uronic acids (UA) [32] and total sugars (TS) [33] content. For UA measurement, the samples were added with $12.5 \mathrm{mM}$ of borate sulfuric acid (Sigma-Aldrich) and after boiling for $5 \mathrm{~min}$, the samples were added with m-phenyl-phenol (Sigma-Aldrich) $(0.15 \%$ in $0.5 \%$ of $\mathrm{NaOH})$. As regard the TS measurement, the samples, as previously prepared, were added with $0.2 \%$ of anthron (Sigma-Aldrich) solution in concentrated $\mathrm{H}_{2} \mathrm{SO}_{4}$ and after boiling for $8 \mathrm{~min}$, the samples were read at the spectrophotometer. For calculation of UA or TS concentrations, spectrophotometric absorbance readings (at 520 and $620 \mathrm{~nm}$, respectively) were evaluated against a standard curve of galacturonic acid (GalA) (Sigma-Aldrich) or glucose (Glc) (SigmaAldrich) respectively. Three replicates for each genotype were analyzed, the experiment was repeated twice and results were expressed as $\mathrm{mg}$ of GalA or Glc $\mathrm{g}^{-1}$ of biomass.

\subsection{GC Method for Measurement of Hemicellulose Sugar Contents of Biomass}

The non-cellulosic neutral sugar (NS) composition was obtained from $2 \mathrm{mg}$ of AIR hydrolyzed in $2 \mathrm{M}$ trifluoroacetic acid (TFA) (Sigma-Aldrich) at $121^{\circ} \mathrm{C}$ for $1 \mathrm{~h} \mathrm{[34]}$ and converted to alditol acetates [35] for gas chromatographic analysis. Aliquots of the derived samples were injected into an Agilent 7890 GC equipped with a Gerstel MPS autosampler, coupled with an Agilent 7000C MSD detector (Palo Alto, CA, USA). The chromatographic separation was performed on a HP-5MS capillary column $(30 \mathrm{~m} \times 0.25 \mathrm{~mm}$, film thickness $0.17 \mu \mathrm{m})$, the following temperature program was used: $160{ }^{\circ} \mathrm{C}$ hold for $2 \mathrm{~min}$, then increased to $220^{\circ} \mathrm{C}$ at a rate of $2.5^{\circ} \mathrm{C} \mathrm{min}-1$, then increased to $240{ }^{\circ} \mathrm{C}$ at a rate of $5{ }^{\circ} \mathrm{C}$ $\mathrm{min}^{-1}$, and finally held at $240^{\circ} \mathrm{C}$ for $5 \mathrm{~min}$. Helium was used as the carrier gas at a constant flow of $1 \mathrm{~mL} \mathrm{~min}^{-1}$ for both columns. The different alditol acetates were identified based on their MS spectra and also by comparison with standards containing myo-inositol (internal standard), rhamnose (Rha), fucose (Fuc), arabinose (Ara), xylose (Xyl), mannose (Man), galactose (Gal), and glucose (Glc). Neutral sugar amounts were calculated relative to the myo-inositol internal standard (Sigma-Aldrich). Three replicates for each genotype were analyzed, the experiment was repeated twice, and results were expressed as mg of neutral sugars $\mathrm{g}^{-1}$ of biomass. 


\subsection{Anthrone Method for Cellulose Content Measurement}

The pellets that remained after hydrolysis were dissolved in $67 \% \mathrm{H}_{2} \mathrm{SO}_{4}$ and assayed using the anthrone (Sigma-Aldrich) reagent, according to Foster et al. [36]. Cellulose content was evaluated considering a standard curve of a $67 \% \mathrm{H}_{2} \mathrm{SO}_{4}$ solution of cellulose powder (Alfa Aesar, Kandel, Germany). Three replicates for each genotype were analyzed, the experiment was repeated twice, and results were expressed as $\mathrm{mg}$ of cellulose $\mathrm{g}^{-1}$ of biomass.

\subsection{Enzymatic Hydrolysis}

The enzymatic hydrolysis was performed after a severe washing step with ethanol, to remove free sugars and other solutes that are not part of the CW, according to the protocol proposed by Van Acker et al. [37] with little modifications for the enzyme mix. In this protocol, it was also suggested to include this step even for samples that will be saccharified without any pretreatment.

Briefly, aliquots of $10 \mathrm{mg}$ of the wheat straw, grinded as described above, were added to $1 \mathrm{~mL}$ of $70 \%(v / v)$ ethanol and incubated overnight at $55^{\circ} \mathrm{C}$. The pellet extracted material was washed 3 times with $1 \mathrm{~mL}$ of $70 \%(v / v)$ ethanol, once with $1 \mathrm{~mL}$ of acetone, and left under nitrogen flow for $30 \mathrm{~min}$. The dried biomass was weighed, and the glucose released after enzymatic hydrolysis was calculated. An enzyme blend composed of cellulases, $\beta$ glucosidases and hemicellulases (Cellic CTec2 and HTec2), kindly provided by Novozyme (Copenhagen, Denmark), was utilized. Prior to utilization, the blend was desalted in a PD-10 Sephadex G-25M (Pharmacia, Berlin, Germany) and diluted 10-fold. Enzyme activity was measured by a filter paper assay. For the enzymatic treatment, the dry biomass was dissolved in $1 \mathrm{~mL}$ of acetic acid buffer solution ( $\mathrm{pH} 4.8)$ and after incubation at $50{ }^{\circ} \mathrm{C}$ for $5 \mathrm{~min}, 0.1$ filter paper units (FPU) were added to the acetic acid buffer. The sugar released after enzymatic digestion was measured with the glucose oxidase-peroxidase (GOD-POD) assay (Sigma, Neustadt an der Weinstrasse, Germany; Roche, Basel, Switzerland), absorbance readings were carried out spectrophotometrically (Multiskan GO Thermo Scientific, Waltham, MA, USA) at a wavelength of $405 \mathrm{~nm}$. Aliquots of $20 \mu \mathrm{L}$ of the supernatant were taken after $0,2,6,24$, and $48 \mathrm{~h}$ of incubation at $50^{\circ} \mathrm{C}$ with shaking at $750 \mathrm{rpm}$ and 30-fold diluted with acetic acid buffer. The concentration in the samples was calculated against a standard curve based on D-glucose concentrations. The glucose released was expressed as $\mathrm{mg} \mathrm{g}^{-1}$ of biomass. Enzymatic saccharification efficiency was calculated as percentage of glucose released after hydrolysis compared to TS. Three biological replicates were used, and the experiment was repeated twice.

\subsection{Statistical Analysis}

Descriptive statistical parameters were calculated, and ANOVA analysis was performed with SigmaPlot ver.13 (Systat Software Inc. Systat Software Erkrath Germany). Spearman's correlation was calculated with cor function (SigmaPlot) between all biochemical traits analyzed. Tukey's Test $(p<0.05)$ to identify significant differences between the means was performed by using Minitab ver.17 (Statistical Software).

\section{Results}

\subsection{Phenotypic Traits}

Phenotypic traits were recorded at complete ripeness (Z94) and are reported in Table 2. Based on differences in main culm length, and according to the classification of plant size previously indicated, three genotypes were classified as large, four as medium, and three as small. Main culm length ranged from $153.1 \mathrm{~cm}$ of line SSD 7 to $95.2 \mathrm{~cm}$ of line SSD 180. A remarkable variability among genotypes was observed with respect to biomass weight. The variety Saragolla, recorded as M size, was the plant with the highest biomass production (91.0 g per plant), about 6.5 folds higher than the line SSD 180, scored as S size, the sample with the lowest biomass production ( $14.1 \mathrm{~g}$ per plant). Significant differences among genotypes were also recorded for kernel yield, in this case, the grain productions 
ranged from $42.9 \mathrm{~g}$ per plant in the line SSD 7 (L size) to $14.0 \mathrm{~g}$ per plant in the S size line SSD 180.

Table 2. Phenotypic traits. Culm length ( \pm SD are reported in brackets), biomass weight, and kernel yield were determined at complete ripeness stage. Data are calculated as the average of ten replicates.

\begin{tabular}{ccccc}
\hline \multirow{2}{*}{ Genotype } & Size & Culm Length (H) & Biomass Weight (B) & Kernel Yield (K) \\
\cline { 3 - 5 } & & $\mathbf{( c m )}$ & $\mathbf{~ ( g ~ P l a n t ~}^{-\mathbf{1}} \mathbf{)}$ & (g Plant $^{-\mathbf{1})}$ \\
\hline SSD 7 & $\mathrm{L}$ & $153.1( \pm 7.56)$ & $69.6^{\mathrm{b}}$ & $42.9^{\mathrm{a}}$ \\
CAPPELLI & $\mathrm{L}$ & $152.2( \pm 7.07)$ & $53.9^{\mathrm{c}}$ & $29.6^{\mathrm{bcd}}$ \\
SSD 283 & $\mathrm{L}$ & $150.3( \pm 6.60)$ & $69.6^{\mathrm{b}}$ & $35.6^{\mathrm{ab}}$ \\
SSD 69 & $\mathrm{M}$ & $145.0( \pm 8.29)$ & $69.3^{\mathrm{b}}$ & $32.2^{\mathrm{bc}}$ \\
SARAGOLLA & $\mathrm{M}$ & $138.3( \pm 8.14)$ & $91.0^{\mathrm{a}}$ & $31.8^{\mathrm{bc}}$ \\
SSD 467 & $\mathrm{M}$ & $120.4( \pm 6.24)$ & $31.2^{\mathrm{de}}$ & $26.0^{\mathrm{bcd}}$ \\
SSD 411 & $\mathrm{M}$ & $116.5( \pm 8.90)$ & $26.8^{\mathrm{ef}}$ & $22.4^{\mathrm{cde}}$ \\
SSD 96 & $\mathrm{S}$ & $110.0( \pm 6.55)$ & $44.9^{\mathrm{cd}}$ & $34.2^{\mathrm{ab}}$ \\
SSD 240 & $\mathrm{S}$ & $98.0( \pm 4.11)$ & $25.3^{\mathrm{ef}}$ & $20.0^{\mathrm{de}}$ \\
SSD 180 & $\mathrm{S}$ & $95.2( \pm 6.32)$ & $14.1^{\mathrm{f}}$ & $14.0^{\mathrm{e}}$ \\
\hline
\end{tabular}

Different lower-case letters, within the same column, indicate values significantly different according to Tukey's multiple range test $(p<0.05)$.

\subsection{Biochemical Characterization of Cell Wall}

Cell wall, cellulose, and uronic acids content were evaluated by spectrophotometric analysis, the amount of these polysaccharides, together with the lignin content and the AIR percentage, are reported in Table 3.

Table 3. Polysaccharide content of cell wall. Cellulose and uronic acids content were expressed as $\mathrm{mg}$ of cellulose or galacturonic acid (GalA) $\mathrm{g}^{-1}$ of biomass. Klason lignin content was expressed as mg of lignin $\mathrm{g}^{-1}$ of biomass. The AIR (alcohol insoluble residue) was expressed as percentage of AIR respect to the biomass.

\begin{tabular}{|c|c|c|c|c|}
\hline Genotype & $\begin{array}{l}\text { AIR } \\
(\%)\end{array}$ & $\begin{array}{c}\text { Cellulose } \\
\left(\mathrm{mg} \mathrm{g}^{-1}\right)\end{array}$ & $\begin{array}{l}\text { Uronic Acids } \\
\quad\left(\mathrm{mg} \mathrm{g}^{-1}\right)\end{array}$ & $\begin{array}{c}\text { Lignin } \\
\left(\mathrm{mg} \mathrm{g}^{-1}\right)\end{array}$ \\
\hline SSD 7 & 83.1 & $234.4^{\mathrm{cd}}$ & $115.0^{\mathrm{ab}}$ & $176.7^{\mathrm{b}}$ \\
\hline SSD 69 & 81.6 & $187.5^{\mathrm{d}}$ & $96.1^{b c}$ & $194.4^{\mathrm{ab}}$ \\
\hline SSD 96 & 81.8 & $347.3^{a}$ & $88.3^{\mathrm{cd}}$ & $211.9^{a b}$ \\
\hline SSD 180 & 81.9 & $259.1^{\mathrm{c}}$ & $75.4^{\mathrm{d}}$ & $230.1^{\mathrm{a}}$ \\
\hline SSD 240 & 77.5 & $183.7^{\mathrm{d}}$ & $98.6^{b c}$ & $182.2^{a b}$ \\
\hline SSD 283 & 78.6 & $327.9^{a b}$ & $112.1^{\mathrm{ab}}$ & $185.4^{\mathrm{ab}}$ \\
\hline SSD 411 & 78.7 & $274.5^{b c}$ & $104.5^{b c}$ & $212.9^{a b}$ \\
\hline SSD 467 & 80.6 & $189.5^{\mathrm{d}}$ & $104.2^{b c}$ & $194.1^{\mathrm{ab}}$ \\
\hline CAPPELLI & 69.9 & $368.1^{\mathrm{a}}$ & $89.8^{\mathrm{cd}}$ & $185.8^{a b}$ \\
\hline SARAGOLLA & 89.4 & $220.3^{\mathrm{cd}}$ & $127.3^{\mathrm{a}}$ & $177.5^{b}$ \\
\hline
\end{tabular}

Different lower-case letters, within the same column, indicate values significantly different according to Tukey's multiple range test $(p<0.05)$.

Significant differences among all genotypes were observed in the cellulose content; the largest quantity was recorded in the varieties Cappelli and SSD 96, with 368.1 and $347.3 \mathrm{mg} \mathrm{g}^{-1}$ of biomass, respectively, which is roughly the double of the amount found in the line with the lowest quantity (SSD 240, $183.7 \mathrm{mg} \mathrm{g}^{-1}$ of biomass). High and significant variation was observed for other genotypes, ranging from 187.5 to $327.9 \mathrm{mg} \mathrm{g}^{-1}$ of biomass for the variety SSD 69 and SSD 283, respectively.

As for uronic acids, the amount of GalA found in the $\mathrm{CW}$ varied from the highest values of the varieties Saragolla and SSD 7 (127.3 and $115.0 \mathrm{mg} \mathrm{g}^{-1}$ of biomass respectively), to the lowest value found in the line SSD 180 (75.4 $\mathrm{mg} \mathrm{g}^{-1}$ of biomass). Significant differences were also found in Klason lignin content. The lowest amounts were recorded in 
samples SSD 7 and Saragolla with 176.7 and $177.5 \mathrm{mg} \mathrm{g}^{-1}$ of biomass, respectively, values that are about $23 \%$ lower than in line SSD 180, where the highest amount of lignin was recorded (230.1 $\mathrm{mg} \mathrm{g}^{-1}$ of biomass). No significant differences were observed among the other lines.

The proportions of the neutral sugars in the hemicelluloses, reported in Figure 1, were measured by GC-MS of alditol acetate derivatives of sugars released by hydrolysis with $2 \mathrm{M}$ TFA, a treatment that does not hydrolyze cellulosic glucans. Regarding the hemicellulose composition, Ara was generally the most abundant sugar in the non-cellulosic polysaccharides fraction of $\mathrm{CW}$, followed by Xyl. In fact, with exception of variety Cappelli, in all other samples Ara and $\mathrm{Xyl}$ averaged around $40 \%$ and $30 \%$, respectively, of the hemicellulose content. Glucose proved to be generally the third most abundant sugar, at much lower amounts than Ara and Xyl, with the exception of Cappelli, SSD 411, and Saragolla, where high quantities of Glc were detected. The galactose content was poor, while mannose was generally not detectable, except for the genotypes SSD 411. Rhamnose and fucose were not detected at all.

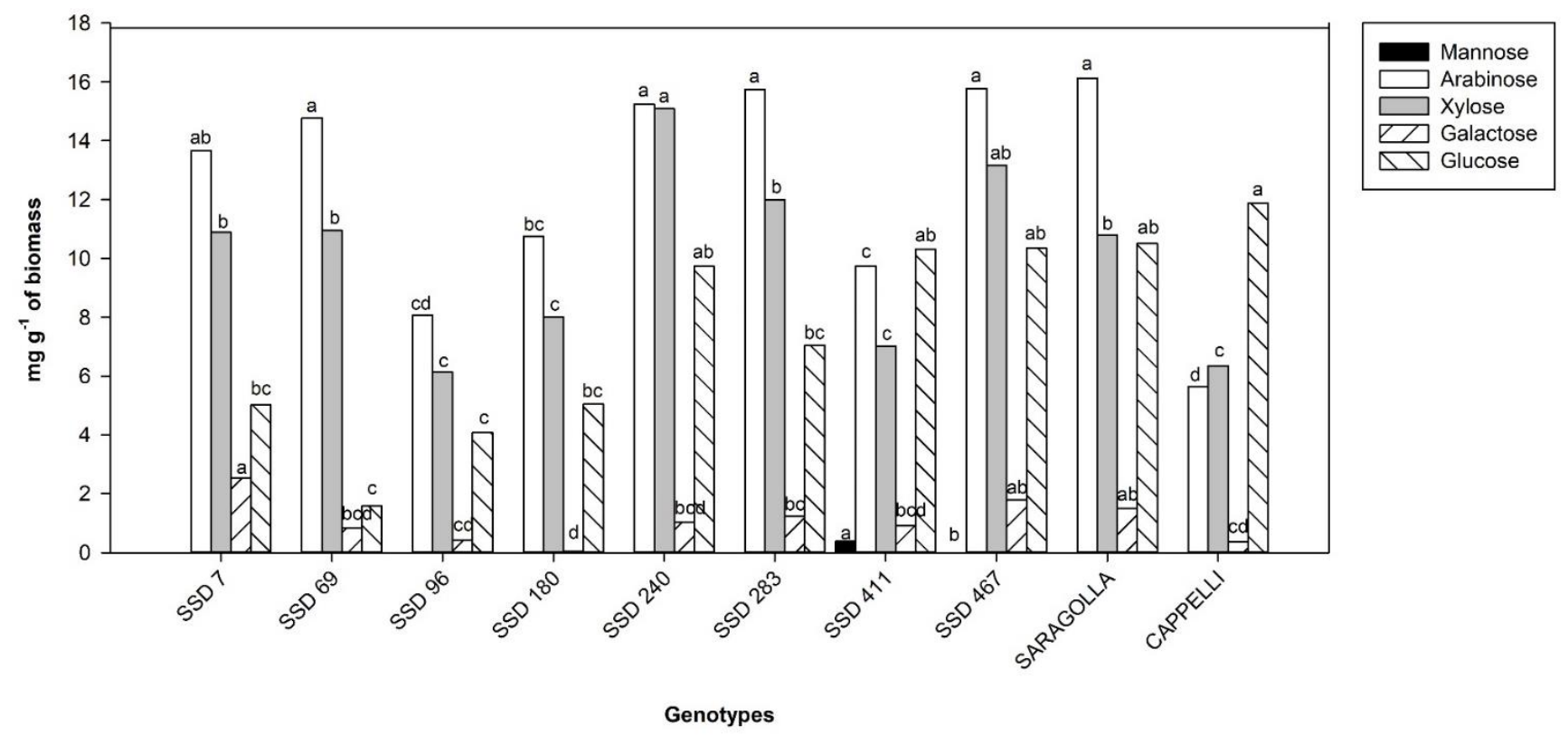

Figure 1. Hemicellulose amounts and composition. Results were expressed as $\mathrm{mg} \mathrm{g}^{-1}$ of biomass. Different lower-case letters, within the same column, indicate values significantly different according to Tukey's multiple range test $(p<0.05)$.

\subsection{Effect of the Lignin Content on Saccharification Efficiency}

After $2 \mathrm{~h}$ from enzymatic hydrolysis, an appreciable variation could be observed among the different genotypes tested, as amount of glucose released, ranging from $26.6 \mathrm{mg}$ (SSD 96) to $54.5 \mathrm{mg}$ (SSD 283) (Figure 2). Moreover, the genotypes SSD 283, Cappelli, SSD 7, Saragolla, SSD 240 and SSD 467, releasing at least $45.4 \mathrm{mg}$ of glucose, appeared to be more promptly able to release this sugar. After $48 \mathrm{~h}$ of enzymatic treatment, the maximum amount of glucose was available. Complete data of the enzymatic hydrolysis after 2, 6, 24, and $48 \mathrm{~h}$, of all genotypes, are shown as Supplementary Materials in Table S1.

In Table 4 are reported the amounts of glucose released after $48 \mathrm{~h}$ and the saccharification efficiency, calculated as the ratio between the glucose released after enzymatic hydrolysis and the TS content. A general view of the percentages of saccharification efficiency, indicated that the genotypes could be divided in twi groups with significant differences (three varieties with the highest and three varieties the lowest values), moreover, a third intermediate group can be also identified, although significant differences were not observed, compared to the previous groups. The wheat lines with the highest saccharification efficiency were SSD 240, Saragolla, and SSD 283, with very similar yields, 
from $16.9 \%$ to $16.8 \%$. The intermediate group could be identified with the lines SSD 7, SSD 411, Cappelli, and SSD 180, with saccharification percentages, from $15.7 \%$ to $14.5 \%$. The third group included the genotypes SSD 69, SSD 467, and SSD 96, with a saccharification yield between 24.3 to $27.7 \%$ lower than the variety SSD 240 . Interestingly, the genotypes with the highest glucose yield, recorded after $2 \mathrm{~h}$, confirmed a superior yield after $48 \mathrm{~h}$.

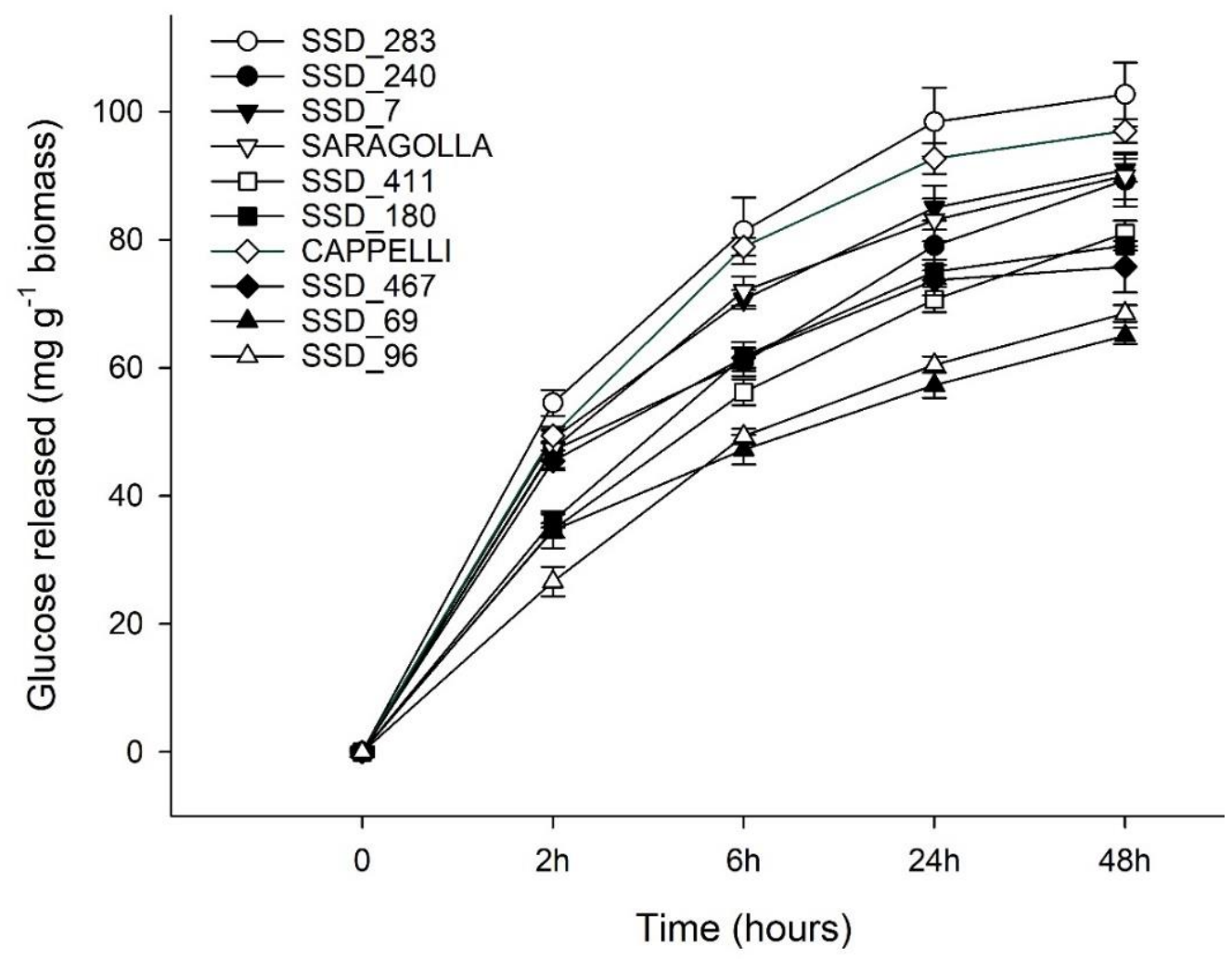

Figure 2. Glucose released after 2, 6, 24, and $48 \mathrm{~h}$ of enzymatic hydrolysis of all genotypes. Results were expressed as mg of glucose $\mathrm{g}^{-1}$ of biomass.

In Table 4 are also reported the values of the ratio between saccharification efficiency per unit of lignin biomass (column S L ${ }^{-1}$ ). The varieties Saragolla, SSD 240, SSD 283, and SS D7 had the highest values among all genotypes (0.095, 0.093, 0.091, and 0.089, respectively). This parameter confirmed, in general, that the saccharification efficiency is inversely correlated to the lignin content. The graph of the relationship between the saccharification efficiency and the glucose yield per unit of lignin content is given as Supplementary Materials (Figure S1).

\subsection{Analysis of the Relationships among Cell Wall Polysaccharides, Lignin, Hydrolysis, and Saccharification Yield}

Spearman's correlation matrix showing the relationships among all variables analyzed in this study and their effects on the enzymatic hydrolysis are reported in Table 5 and in Figure S2 as Supplementary Materials.

A significant negative correlation was observed between the lignin content and the glucose released after hydrolysis $(\mathrm{s}=-0.46 ; p<0.05)$, moreover, a negative and significant correlation was observed between lignin and uronic acid $(\mathrm{s}=-0.52 ; p<0.01)$ and no correlation was evidenced between lignin and cellulose component. A weak and negative relationship between lignin and saccharification yield was also observed $(\mathrm{s}=-0.29$; $p=0.121)$. It is interesting the significant and positive correlation between saccharification and culm length $(\mathrm{s}=0.38 ; p<0.05)$.

The glucose released after hydrolysis showed a significant positive correlation with saccharification efficiency ( $\mathrm{s}=0.90 ; p<0.01)$, uronic acids $(\mathrm{s}=0.41 ; p<0.05)$, and culm 
length ( $\mathrm{s}=0.50 ; p<0.01$ ). A positive correlation, even though not significant, was also found among glucose released and biomass weight and grain yield $(\mathrm{s}=0.30 ; p=0.105$ and $s=0.29 ; p=0.119$, respectively). It is interesting the significant positive correlation among uronic acids and the three parameters biomass weight $(\mathrm{s}=0.47 ; p<0.01)$, grain yield $(s=0.48 ; p<0.01)$, and culm length $(s=0.53 ; p<0.01)$.

The most abundant hemicelluloses recorded among genotypes were Ara and Xyl, which were positive correlated $(\mathrm{s}=0.40 ; p<0.05)$, Ara presenting a weak and negative correlation with saccharification ( $\mathrm{s}=-0.28 ; p=0.137$ ), while Xyl was negatively correlated with culm length and biomass weight $(\mathrm{s}=-0.37 ; p<0.05$ and $\mathrm{s}=-0.38 ; p<0.05)$.

Table 4. Saccharification was expressed as percentage of glucose released after hydrolysis with respect to total sugars. The value $\mathrm{S} \mathrm{L}^{-1}$ was calculated as the ratio between saccharification and lignin content.

\begin{tabular}{ccc}
\hline Genotype & $\begin{array}{c}\text { Saccharification } \\
(\mathbf{\%})\end{array}$ & $\mathbf{S ~ L ~}^{-\mathbf{1}}$ \\
\hline SSD 240 & $16.9^{\mathrm{a}}$ & 0.093 \\
SARAGOLLA & $16.8^{\mathrm{a}}$ & 0.095 \\
SSD 283 & $16.8^{\mathrm{a}}$ & 0.091 \\
SSD 7 & $15.7^{\mathrm{ab}}$ & 0.089 \\
SSD 411 & $15.1^{\mathrm{abc}}$ & 0.071 \\
CAPPELLI & $14.9^{\mathrm{abc}}$ & 0.08 \\
SSD 180 & $14.5^{\mathrm{abc}}$ & 0.063 \\
SSD 69 & $12.8^{\mathrm{bc}}$ & 0.066 \\
SSD 467 & $12.5^{\mathrm{c}}$ & 0.065 \\
SSD 96 & $12.3^{\mathrm{c}}$ & 0.058 \\
\hline
\end{tabular}

Different lower-case letters, within the same column, indicate values significantly different according to Tukey's multiple range test $(p<0.05)$.

Table 5. Spearman's correlation coefficient matrix. Pairwise correlation analyses were performed for all assayed genotypes. The panel above the diagonal shows $p$-values. The panel below the diagonal shows Spearman's correlation coefficients (significant data are marked in bold).

\begin{tabular}{|c|c|c|c|c|c|c|c|c|c|c|}
\hline & Lignin & $\begin{array}{l}\text { Glucose } \\
\text { Released }\end{array}$ & Saccharif. & Ara & Xyl & Cell. & $\begin{array}{l}\text { Uronic } \\
\text { Acids }\end{array}$ & $\begin{array}{l}\text { Culm } \\
\text { Length }\end{array}$ & $\begin{array}{l}\text { Biomass } \\
\text { Weight }\end{array}$ & $\begin{array}{l}\text { Grain } \\
\text { Yield }\end{array}$ \\
\hline Lignin & 0 & 0.010 & 0.121 & 0.393 & 0.422 & 0.503 & 0.003 & 0.004 & 0.001 & 0.015 \\
\hline $\begin{array}{l}\text { Glucose } \\
\text { released }\end{array}$ & -0.460 & 0 & 0.000 & 0.353 & 0.421 & 0.135 & 0.023 & 0.005 & 0.105 & 0.119 \\
\hline Saccharification & -0.290 & 0.900 & 0 & 0.137 & 0.596 & 0.113 & 0.418 & 0.038 & 0.562 & 0.450 \\
\hline Arabinose & 0.160 & -0.180 & -0.280 & 0 & 0.029 & 0.717 & 0.590 & 0.758 & 0.860 & 0.219 \\
\hline Xylose & 0.150 & -0.150 & -0.090 & 0.400 & 0 & 0.126 & 0.502 & 0.041 & 0.039 & 0.380 \\
\hline Cellulose & 0.130 & 0.280 & 0.300 & -0.070 & -0.290 & 0 & 0.324 & 0.319 & 0.662 & 0.038 \\
\hline Uronic acids & -0.520 & 0.410 & 0.150 & 0.100 & -0.130 & -0.190 & 0 & 0.002 & 0.008 & 0.008 \\
\hline Culm length & -0.510 & 0.500 & 0.380 & -0.060 & -0.370 & 0.190 & 0.530 & 0 & 0.000 & 0.000 \\
\hline $\begin{array}{l}\text { Biomass } \\
\text { weight }\end{array}$ & -0.560 & 0.300 & 0.110 & 0.030 & -0.380 & 0.090 & 0.470 & 0.670 & 0 & 0.000 \\
\hline Grain yield & -0.440 & 0.290 & 0.140 & 0.230 & -0.170 & 0.380 & 0.480 & 0.670 & 0.750 & 0 \\
\hline
\end{tabular}

\section{Discussion}

In the present study, the variability of the lignocellulosic biomass of eight durum wheat genotypes and two Italian varieties was evaluated to identify the samples with the lowest recalcitrance to enzymatic hydrolysis without pretreatment.

A high degree of variability was retrieved in the analyzed genotypes, suggesting that the difference in the response to enzymatic treatment can rely on different factors, such as different chemical composition or different structural organization of the lignocellulosic components. 
Our results confirmed lignin as the major factor determining recalcitrance to enzymatic hydrolysis of wheat straw, as demonstrated by the negative correlation between lignin content and the amount of glucose released after enzymatic hydrolysis. Although lignin content was not significantly correlated to saccharification efficiency, the data showed a tendency towards a reduction of this latter parameter as the lignin amount increased. These results agree with previous studies in transgenic alfalfa lines, tobacco, maize, poplar, and Arabidopsis [20,37-41]. It has been widely reported in transgenic poplars and in Arabidopsis that the reduction in lignin content can be compensated by an increase in cellulose $[37,42,43]$.

In this study, a lack of correlation was observed between cellulose and lignin content, but a negative and significant correlation was observed between lignin and uronic acid, as a component of matrix polysaccharide. Similar response was observed in a previous study [37] where the reduction in lignin content was compensated for by an increase in matrix polysaccharides, rather than an increase in cellulose. This might depend on plant physiological response, but further research will be required to shed light on CW relations.

A few studies focused on the influence of $\mathrm{CW}$ polysaccharides on saccharification process, particularly cellulose and hemicellulose amount and composition [44,45]. The predominant hemicellulosic polysaccharides present in the $\mathrm{CW}$ of the studied genotypes were arabinoxylans, in accordance with literature data [46]. The data showed a tendency to a negative trend between saccharification efficiency and Ara content, although a significant correlation was not found. Moreover, considering the positive correlation between Ara and Xyl, it is conceivable that the saccharification effectiveness could be affected by the hemicellulose composition $[47,48]$, particularly the amount of arabinoxylans, as reported by Sumiyoshi et al. [49], rather than the cellulose content.

The analysis of the Spearman's correlation revealed that UA were negatively related to lignin content, while being positively correlated to the glucose released after enzymatic hydrolysis. Many studies reported the influences of UA as a useful approach for enhancing biomass enzymatic digestibility in some crops. [50]. The main pectic polysaccharides are rich in GalA residues that form homogalacturonans (HGs), synthesized and secreted as a highly methyl-esterified polymer. Pectin methylesterases (PMEs) catalyze the demethylesterification of HGs, promoting the formation of long stretches of negatively charged carboxylic groups that contribute to $\mathrm{Ca}^{2+}$ cross-links, promoting the formation of the "egg-box" [51]. These rigid structures enhance CW stiffening and cell-cell adhesion, increasing the recalcitrance to cellulases activity. Lionetti et al. [52] showed that the recalcitrance of CW to enzymatic saccharification was reduced in leaves and stems of plants overexpressing pectin methylesterases inhibitor (PMEI).

Many studies also reported that high values of methyl esterification of the HGs promote cell expansion, positively affecting plant growth and biomass yield [52-54]. In our study, a positive correlation was observed between UA and culm length, as well as between UA and biomass production. Moreover, the UA were positively correlated with the glucose released after hydrolysis and the kernel production. These results, in agreement with the previously reported studies, suggested the presence, in the CW of the selected genotypes, of HGs with a high methylation degree and consequently a low level of egg-box structures, a factor that negatively affects the enzymatic hydrolysis process.

Plants morphology and their chemical composition can affect enzymatic digestibility [55]. In the present study both sugar released after enzymatic hydrolysis and saccharification had a positive correlation with main culm length. This result is in agreement with the study of Lindedam et al. [24] that showed that the structure of taller plants would be more suitable for pretreatment and enzymatic hydrolysis, with a positive influence on the conversion of sugars, compared to shorter plants. On the contrary, a negative correlation was found between main culm length and lignin content. Moreover, it has been reported that the lignin content was the predominant CW factor that enhances lodging resistance in many cereal crops. Lodging is an important agronomic trait because it causes significant yield losses and reduces the quality of the grain and harvesting efficiency. 
The correlation analysis between CW composition and plant morphological characteristic revealed that the lignin-enhanced rice lodging resistance by increasing the mechanical strength of the stem and reducing plant height [56]. In our study we showed that the plant height was positively correlated with a lower CW recalcitrance to enzymatic hydrolysis. Further investigation could be important to assess if the durum wheat genotypes less recalcitrant are more or less susceptible to lodging.

It is interesting to note that no correlation between grain yield and glucose released after enzymatic hydrolysis was found. This occurrence suggests that the two characters may not be genetically associated. If this lack of association will be confirmed by further studies, it would be possible to select wheat genotypes that produce high-quality straw without compromising grain yield.

Based on the results of the present study, two durum wheat genotypes, SSD 7 and SSD 283, can be considered as good models for the integrated production of grain for food use and biomass with good characteristics as feedstock for bioethanol production.

\section{Conclusions}

The present study demonstrated a variability among the examined genotypes, in the sugar release after enzymatic hydrolysis without pretreatment, with significant differences in the saccharification efficiency.

The main factor affecting the glucose released and the saccharification efficiency was the lignin content, which hinders the access of cellulases to CW polysaccharides. In addition, the hemicellulose and UA amount and composition could affect the saccharification efficiency.

Plant morphology also appeared to be related to the enzymatic digestibility of the sugars; the structure of taller plants appeared to be more favorable to the release of glucose after hydrolysis, as compared to shorter plants.

The results confirmed that among the large amount of wheat diversity, stored in gene banks there are genotypes characterized by lower recalcitrance to enzymatic hydrolysis and high grain yield, characteristics that contribute to making the biorefining of wheat straw more profitable.

The present study allowed to identify two durum wheat genotypes possessing characteristics more favorable to producing renewable source for biofuel, also maintaining a good level of kernel yield. This occurrence sheds a light of confidence on the possibility of using wheat genetic diversity to produce a new wheat ideotype for more efficient land use.

Further research is needed for a better understanding of the interconnections between the polysaccharide matrix and lignin content in the enzymatic digestion process.

Supplementary Materials: The following are available online at https:/ / www.mdpi.com/article/10 $.3390 /$ en14227735/s1, Figure S1: Relationship between the saccharification efficiency and the glucose yield per unit of lignin, Figure S2: Spearman's correlation matrix showing the relationships among all variables, Table S1: Glucose released after 2, 6, 24, and $48 \mathrm{~h}$ of enzymatic hydrolysis.

Author Contributions: Conceptualization, D.D., I.M. and T.V.; methodology, I.M., S.M. and G.L.P.; software, D.D.; validation, D.D., I.M., S.M., I.D.B. and T.V.; formal analysis, G.L.P.; investigation, D.D., I.M.; resources, D.P. and M.J.; data curation, D.D. and T.V.; writing—original draft preparation, D.D., I.M. and T.V.; writing-review and editing, D.D., M.J. and T.V.; visualization, D.P.; supervision, D.P.; project administration, F.C.; funding acquisition, D.P. All authors have read and agreed to the published version of the manuscript.

Funding: This research was partly funded by the program "Progetto per l'attuazione delle attività contenute nel programma triennale 2017-2019 per l'implementazione del Trattato internazionale sulle risorse fitogenetiche per l'alimentazione e l'agricoltura. DM 10271 del 22.03.2017" awarded to IBBR URT Metapontum Agrobios by the Italian Ministry of Agriculture and the EMPHASIS PREP project (European Infrastructure for multi-scale Plant Phenomics and Simulation for food security in a changing climate) grant no. 739514.

Data Availability Statement: Not applicable. 
Acknowledgments: The authors wish to thank Salvatore Marceddu and Antonello Petretto for technical assistance.

Conflicts of Interest: The authors declare no conflict of interest.

\section{References}

1. Demirbas, A. Political, Economic and Environmental Impacts of Biofuels: A Review. Appl. Energy 2009, 86, S108-S117. [CrossRef]

2. Voloshin, R.; Rodionova, M.V.; Zharmukhamedov, S.K.; Veziroglu, T.N.; Allakhverdiev, S.I. Review: Biofuel Production from Plant and Algal Biomass. Int. J. Hydrogen Energy 2016, 41, 17257-17273. [CrossRef]

3. Asgher, M.; Ahmad, Z.; Iqbal, H.M.N. Alkali and Enzymatic Delignification of Sugarcane Bagasse to Expose Cellulose Polymers for Saccharification and Bio-Ethanol Production. Ind. Crop. Prod. 2013, 44, 488-495. [CrossRef]

4. Fatma, S.; Hameed, A.; Noman, M.; Ahmed, T.; Sohail, I.; Shahid, M.; Tariq, M.; Tabassum, R. Lignocellulosic Biomass: A Sus-tainable Bioenergy Source for Future. Protein Pept. Lett. 2018, 25, 20-25. [CrossRef]

5. Andrade de Sá, S.; Palmer, C.; Engel, S. Ethanol Production, Food and Forests. Environ. Resour. Econ. 2012, 51, 1-21. [CrossRef]

6. Sims, R.E.; Mabee, W.; Saddler, J.N.; Taylor, M. An Overview of Second Generation Biofuel Technologies. Bioresour. Technol. 2010, 101, 1570-1580. [CrossRef]

7. Chandra, R.P.; Bura, R.; Mabee, W.E.; Berlin, A.; Pan, X.; Saddler, J.N. Substrate Pretreatment: The Key to Effective Enzymatic Hydrolysis of Lignocellulosics? Biofuels 2007, 108, 67-93. [CrossRef]

8. Cosgrove, D.C.; Jarvis, M.C. Comparative Structure and Biomechanics of Plant Primary and Secondary Cell Walls. Front. Plant Sci. 2012, 3, 204. [CrossRef]

9. Miedes, E.; Vanholme, R.; Boerjan, W.; Molina, A. The Role of the Secondary Cell Wall in Plant Resistance to Pathogens. Front. Plant Sci. 2014, 5, 358. [CrossRef]

10. Boerjan, W.; Ralph, J.; Baucher, M. Lignin Biosynthesis. Annu. Rev. Plant Biol. 2003, 54, 519-546. [CrossRef]

11. Vanholme, R.; Demedts, B.; Morreel, K.; Ralph, J.; Boerjan, W. Lignin Biosynthesis and Structure. Plant Physiol. 2010, 153, 895-905. [CrossRef]

12. Lourenço, A.; Pereira, H. Compositional Variability of Lignin in Biomass. IntechOpen 2018, 153, 895-905. [CrossRef]

13. Pensupa, N.; Jin, M.; Kokolski, M.; Archer, D.B.; Du, C. A Solid State Fungal Fermentation-Based Strategy for the Hydrolysis of Wheat Straw. Bioresour. Technol. 2013, 149, 261-267. [CrossRef]

14. Tishler, Y.; Samach, A.; Rogachev, I.; Elbaum, R.; Levy, A.A. Analysis of Wheat Straw Biodiversity for Use as a Feedstock for Biofuel Production. BioEnergy Res. 2015, 8, 1831-1839. [CrossRef]

15. Cao, G.; Zhang, X.-Y.; Gong, S.; Zheng, F. Investigation on Emission Factors of Particulate Matter and Gaseous Pollutants from Crop Residue Burning. J. Environ. Sci. 2008, 20, 50-55. [CrossRef]

16. Li, S.; Chen, G. Agricultural waste-derived superabsorbent hydrogels: Preparation, performance, and socioeconomic impacts. J. Clean. Prod. 2019, 251, 119669. [CrossRef]

17. Wang, Y.; Fan, C.; Hu, H.; Li, Y.; Sun, D.; Wang, Y.; Peng, L. Genetic Modification of Plant Cell Walls to Enhance Biomass Yield and Biofuel Production in Bioenergy Crops. Biotechnol. Adv. 2016, 34, 997-1017. [CrossRef]

18. Iqbal, H.M.N.; Kyazze, G.; Keshavarz, T. Advances in the Valorization of Lignocellulosic Materials by Biotechnology: An Over-View. BioResources 2013, 8, 3157-3176. [CrossRef]

19. Himmel, M.E.; Ding, S.-Y.; Johnson, D.K.; Adney, W.S.; Nimlos, M.R.; Brady, J.W.; Foust, T.D. Biomass Recalcitrance: Engineering Plants and Enzymes for Biofuels Production. Science 2007, 315, 804-807. [CrossRef]

20. Chen, F.; Dixon, A.; Lignin, R. Modification Improves Fermentable Sugar Yields for Biofuel Production. Nat. Biotechnol. 2007, 25, 759-761. [CrossRef]

21. Van Acker, R.; Leplé, J.-C.; Aerts, D.; Storme, V.; Goeminne, G.; Ivens, B.; Légée, F.; Lapierre, C.; Piens, K.; Van Montagu, M.C.E.; et al. Improved Saccharification and Ethanol Yield from Field-Grown Transgenic Poplar Deficient in Cinnamoyl-CoA Reductase. Proc. Natl. Acad. Sci. USA 2014, 111, 845-850. [CrossRef]

22. Wu, Z.; Zhang, M.; Wang, L.; Tu, Y.; Zhang, J.; Xie, G.; Zou, W.; Li, F.; Guo, K.; Li, Q.; et al. Peng, Biomass Digestibility is Pre-Dominantly Affected by Three Factors of Wall Polymer Features Distinctive in Wheat Accessions and Rice Mutants. Biotechnol. Biofuels 2013, 6, 1-14. [CrossRef]

23. Wu, Z.; Hao, H.; Zahoor; Tu, Y.; Hu, Z.; Wei, F.; Liu, Y.; Zhou, Y.; Wang, Y.; Xie, G.; et al. Diverse Cell Wall Composition and Varied Biomass Digestibility in Wheat Straw for Bioenergy Feedstock. Biomass. Bioenergy 2014, 70, 347-355. [CrossRef]

24. Lindedam, J.; Andersen, S.; DeMartini, J.; Bruun, S.; Jørgensen, H.; Felby, C.; Magid, J.; Yang, B.; Wyman, C. Cultivar Variation and Selection Potential Relevant to the Production of Cellulosic Ethanol from Wheat Straw. Biomass. Bioenergy 2012, 37, 221-228. [CrossRef]

25. Pignone, D.; De Paola, D.; Rapanà, N.; Janni, M. Single Seed Descent: A Tool to Exploit Durum Wheat (Triticum durum Desf.) Genetic Resources. Genet. Resour. Crop. Evol. 2015, 62, 1029-1035. [CrossRef]

26. Pignone, D.; De Paola, D.; Rapanà, N.; Janni, M.; Maxted, N.; Dulloo, M.E.; Ford-Lloyd, B.V. Capturing Wild Relative and Landrace Diversity for Crop Improvement Using a New Selection Tool to Exploit Genetic Resources in Durum Wheat (Triticum durum Desf.). Chapter 6; In Enhancing Crop Genepool Use; CABI: Boston, MA, USA, 2016; pp. 47-53. [CrossRef]

27. Zadoks, J.C.; Chang, T.T.; Konzak, C.F. A Decimal Code for the Growth Stages of Cereals. Weed Res. 1974, 14, 415-421. [CrossRef] 
28. Slafer, G.A.; Halloran, G.M.; Connor, D.J. Influence of Photoperiod on Culm Length in Wheat. Field Crop. Res. 1995, 40, 95-99. [CrossRef]

29. Sluiter, A.; Ruiz, R.; Scarlata, C.; Sluiter, J.; Templeton, D. Determination of Extractives, in Biomas; NREL/TP-510-42619; National Renewable Energy Laboratory: Golden, CO, USA, 2008; pp. 1-12.

30. Sluiter, A.; Hames, B.; Ruiz, R.; Scarlata, C.; Sluiter, J.; Templeton, D.; Crocker, D. Determination of Structural Carbohydrates and Lignin in Biomass; NREL/TP-510-42618; National Renewable Energy Laboratory: Golden, CO, USA, 2012; pp. 1-18.

31. Ahmed, A.E.R.; Labavitch, J.M. A Simplified Method for Accurate Determination of Cell Wall Uronide Content. J. Food Biochem. 1978, 1, 361-365. [CrossRef]

32. Blumenkrantz, N.; Asboe-Hansen, G. New Method for Quantitative Determination of Uronic Acids. Anal. Biochem. 1973, 54, 484-489. [CrossRef]

33. Yemm, E.W.; Willis, A.J. The Estimation of Carbohydrates in Plant Extracts by anthrone. Biochem. J. 1954, 57, 508-514. [CrossRef]

34. Albersheim, P.; Nevins, D.J.; English, P.D.; Karr, A. A Method for the Analysis of Sugars in Plant Cell-Wall Polysaccharides by Gas-Liquid Chromatography. Carbohydr. Res. 1967, 5, 340-345. [CrossRef]

35. Blakeney, A.B.; Harris, P.J.; Henry, R.; Stone, B.A. A Simple and Rapid Preparation of Alditol Acetates for Monosaccharide Analysis. Carbohydr. Res. 1983, 113, 291-299. [CrossRef]

36. Foster, C.E.; Martin, T.M.; Pauly, M. Comprehensive Compositional Analysis of Plant Cell Walls (Lignocellulosic biomass) Part II: Carbohydrates. J. Vis. Exp. 2010, 37, e1837. [CrossRef] [PubMed]

37. Van Acker, R.; Vanholme, R.; Storme, V.; Mortimer, J.C.; Dupree, P.; Boerjan, W. Lignin Biosynthesis Perturbations Affect Sec-Ondary Cell Wall Composition and Saccharification Yield in Arabidopsis thaliana. Biotechnol. Biofuels. 2013, 6, 1-17. [CrossRef]

38. Cook, C.M.; Daudi, A.; Millar, D.J.; Bindschedler, L.V.; Khan, S.; Bolwell, G.P.; Devoto, A. Transcriptional Changes Related to Secondary Wall Formation in Xylem of Transgenic Lines of Tobacco Altered for Lignin or Xylan Content which Show Improved Saccharification. Phytochemistry 2012, 74, 79-89. [CrossRef]

39. Fornale, S.; Capellades, M.; Encina, A.; Wang, K.; Irar, S.; Lapierre, C.; Ruel, K.; Joseleau, J.-P.; Berenguer, J.; Puigdomènech, P.; et al. Altered Lignin Biosynthesis Improves Cellulosic Bioethanol Production in Transgenic Maize Plants Down-Regulated for Cinnamyl Alcohol Dehydrogenase. Mol. Plant 2012, 5, 817-830. [CrossRef]

40. Mansfield, S.D.; Kang, K.-Y.; Chapple, C. Designed for Deconstruction-Poplar Trees Altered in Cell Wall Lignification Improve the Efficacy of Bioethanol Production. New Phytol. 2012, 194, 91-101. [CrossRef]

41. Studer, M.; DeMartini, J.D.; Davis, M.; Sykes, R.W.; Davison, B.; Keller, M.; Tuskan, G.; Wyman, C.E. Lignin Content in Natural Populus Variants Affects Sugar Release. Proc. Natl. Acad. Sci. USA 2011, 108, 6300-6305. [CrossRef]

42. Hu, W.-J.; Harding, S.A.; Lung, J.; Popko, J.L.; Ralph, J.; Stokke, D.D.; Tsai, C.-J.; Chiang, V.L. Repression of Lignin Biosynthesis Promotes Cellulose Accumulation and Growth in Transgenic Trees. Nat. Biotechnol. 1999, 17, 808-812. [CrossRef]

43. Jouanin, L.; Goujon, T.; de Nadai, V.; Martin, M.-T.; Mila, I.; Vallet, C.; Pollet, B.; Yoshinaga, A.; Chabbert, B.; Petit-Conil, M.; et al. Lignification in Transgenic Poplars with Extremely Reduced Caffeic Acid O-Methyltransferase Activity. Plant Physiol. 2000, 123, 1363-1374. [CrossRef]

44. Papa, G.; Varanasi, P.; Sun, L.; Cheng, G.; Stavila, V.; Holmes, B.; Simmons, B.; Adani, F.; Singh, S. Exploring the Effect of Different Plant Lignin Content and Composition on Ionic Liquid Pretreatment Efficiency and Enzymatic Saccharification of Eucalyptus globulus L. Mutants. Bioresour. Technol. 2012, 117, 352-359. [CrossRef]

45. Lee, K.J.; Marcus, S.E.; Knox, J.P. Cell Wall Biology: Perspectives from Cell Wall Imaging. Mol. Plant 2011, 4, 212-219. [CrossRef]

46. Albersheim, P.; Darvill, A.; Roberts, K.; Sederoff, R.; Staehelin, A. Plant Cell Walls; Garland Science, Taylor \& Francis Group LLC: New York, NY, USA, 2011.

47. Xu, N.; Zhang, W.; Ren, S.; Liu, F.; Zhao, C.; Liao, H.; Xu, Z.; Huang, J.; Li, Q.; Tu, Y.; et al. Hemicelluloses Negatively Affect Lignocellulose Crystallinity for High Biomass Digestibility under $\mathrm{NaOH}$ and $\mathrm{H}_{2} \mathrm{SO}_{4}$ Pretreatments in Miscanthus. Biotechnol. Biofuels 2012, 5, 58. [CrossRef]

48. Li, F.; Zhang, M.; Guo, K.; Hu, Z.; Zhang, R.; Feng, X.; Yi, W.; Zou, L.; Wang, C.; Wu, J.; et al. Peng, High-Level Hemicellulosic Arabinose Predominately Affects Lignocellulose Crystallinity for Genetically Enhancing Both Plant Lodging Re-Sistance and Biomass Enzymatic Digestibility in Rice Mutants. Plant Biotechnol. J. 2015, 13, 514-525. [CrossRef]

49. Sumiyoshi, M.; Nakamura, A.; Nakamura, H.; Hakata, M.; Ichikawa, H.; Hirochika, H.; Ishii, T.; Satoh, S.; Iwai, H. Increase in Cellulose Accumulation and Improvement of Saccharification by Overexpression of Arabinofuranosidase in Rice. PLoS ONE 2013, 8, e78269. [CrossRef]

50. Wang, Y.; Huang, J.; Li, Y.; Xiong, K.; Wang, Y.; Li, F.; Liu, M.; Wu, Z.; Tu, Y.; Peng, L. Ammonium Oxalate-Extractable Uronic Acids Positively Affect Biomass Enzymatic Digestibility by Reducing Lignocellulose Crystallinity in Miscanthus. Bioresour. Technol. 2015, 196, 391-398. [CrossRef]

51. Venditti, T.; D’hallewin, G.; Ladu, G.; Petretto, G.L.; Pintore, G.; Labavitch, J.M. Effect of $\mathrm{NaHCO}_{3}$ Treatments on the Activity of the Cell-Wall Degrading Enzymes Produced by Penicillium Digitatum during the Pathogenesis Process on Grapefruit. J. Sci. Food Agric. 2018, 98, 4928-4936. [CrossRef]

52. Lionetti, V.; Francocci, F.; Ferrari, S.; Volpi, C.; Bellincampi, D.; Galletti, R.; D’Ovidio, R.; De Lorenzo, G.; Cervone, F. Engineering the Cell Wall by Reducing De-Methyl-Esterified Homogalacturonan Improves Saccharification of Plant Tissues for Bioconversion Proc. Natl. Acad. Sci. USA 2009, 107, 616-621. [CrossRef] 
53. Lionetti, V.; Raiola, A.; Camardella, L.; Giovane, A.; Obel, N.; Pauly, M.; Favaron, F.; Cervone, F.; Bellincampi, D. Overexpression of Pectin Methylesterase Inhibitors in Arabidopsis Restricts Fungal Infection by Botrytis cinerea. Plant Physiol. 2007, 143, 1871-1880. [CrossRef]

54. Derbyshire, P.; McCann, M.C.; Roberts, K. Restricted Cell Elongation in Arabidopsis hypocotyls is Associated with a Reduced Av-erage Pectin Esterification Level. BMC Plant Biol. 2007, 7, 31. [CrossRef]

55. Tolera, A.; Tsegaye, B.; Berg, T. Effects of Variety, Cropping Year, Location and Fertilizer Application on Nutritive Value of Durum Wheat Straw. J. Anim. Physiol. Anim. Nutr. 2008, 92, 121-130. [CrossRef]

56. Liu, S.; Huang, Y.; Xu, H.; Zhao, M.; Xu, Q.; Li, F. Genetic Enhancement of Lodging Resistance in Rice due to the Key Cell Wall Polimer Lignin, which Affects Stem Characteristics. Breed. Sci. 2018, 68, 508-515. [CrossRef] 